\title{
EVALUATION OF A LIPOPEPTIDE BIOSURFACTANT FROM BACILLUS NATTO TK-1 AS A POTENTIAL SOURCE OF ANTI-ADHESIVE, ANTIMICROBIAL AND ANTITUMOR ACTIVITIES
}

\author{
Xiao-Hong Cao ${ }^{1 *}$; Zhen-Yu Liao ${ }^{1}$; Chun-Ling Wang ${ }^{1}$; Wen-Yan Yang ${ }^{2}$; Mei-Fang Lu$^{1}$ \\ ${ }^{1}$ School of Food Science and Biotechnology, Tianjin University of Science and Technology, Tianjin 300457, PR China; \\ ${ }^{2}$ School of Marine Science and Engineering, Tianjin University of Science and Technology, Tianjin 300457, PR China
}

Submitted: November 07, 2007; Returned to authors for corrections: December 06, 2007; Approved: February 15, 2009.

\begin{abstract}
A lipopeptide biosurfactant produced by Bacillus natto TK-1 has a strong surface activity. The biosurfactant was found to be an anti-adhesive agent against several bacterial strains, and also showed a broad spectrum of antimicrobial activity. The biosurfactant induced a significant reduction in tumor cells viability in a dosedependent manner.
\end{abstract}

Key words: Biosurfactant, anti-adhesive, antimicrobial activity, antitumor

Microbial compounds which exhibit pronounced surface activity are classified as biosurfactants. Biosurfactants including a structurally diverse group are produced by several types of microorganisms such as bacteria, yeasts and fungi as membrane components or secondary metabolites $(9,19,25)$. They attracted attention as hydrocarbon dissolution agents for the first time in the late 1960s (1). In recent years, the interest in biosurfactants has been remarkably increasing due to many advantages compared with chemical surfactants, including lower toxicity, biodegradability, ecological acceptability, complex molecules and specific activity at extreme conditions (temperature, $\mathrm{pH}$, salinity) (32,45).

Among the many classes of biosurfactants, lipopeptides represent a class of microbial surfactant with remarkable surface properties and biological activities, such as surplus crude oil recovery, food-processing, de-emulsification, antimicrobial and antitumor, antiviral, antiadhesive activities and so on $(3,4,17,18,33,41)$. Surfactin, produced by various Bacillus subtilis strains, is one of the most powerful and effective lipopeptide-type biosurfactant so far known, which is consisted of a seven amino acids linked via a lactone bond to a $\beta$-hydroxy fatty acid with 13,14 or 15 carbon atoms $(5,15)$. Apart from many characteristic functional activities of biosurfactants, surfactin can also inhibits fibrin clot formation, induces formation of ion channels in lipid bilayer membranes and inhibits cyclic adenosine monophosphate (cAMP) $(1,4,24)$. In addition, a good number of authors have documented that the antiviral action of surfactin is primarily due to a physiochemical interaction between the membrane active surfactant and the virus lipid membrane (37).

Atomic force microscope (AFM) is a powerful imaging tool which has been frequently employed to image a wide variety of samples under a wide variety of conditions. In the past years, AFM has created remarkable interest in applying it to the study of biological structures. Images have appeared in the literature showing DNA, single proteins, structures such as gap junctions, and living cells $(22,27,28,29)$.

Natto is a traditional Japanese food. Recently, its medical benefits are widely recognized in Japan resulting in its increased popularity. Some of its beneficial effects are prevention of heart attacks, strokes, cancer, osteoporosis, obesity and intestinal disease caused by pathogens $(10,14)$. Bacillus natto, an edible strain, identified as $B$. subtilis, is claimed to be the organism mainly responsible for natto fermentation. Moreover, ingestion of Bacillus natto cells is safe for humans under normal host condition (40).

Bacillus natto TK-1, which produces an effective biosurfactant, was provided by TUST Collection Center (Tianjin University of Science and Technology, Tianjin, China). The biosurfactant was determined to be a lipopeptide consisting of

*Corresponding Author. Mailing address: School of Food Science and Biotechnology, Tianjin University of Science and Technology, Tianjin 300457, PR China. Tel.: (86) 022-60601428; Fax: (86) 22-60601332. E-mail: caoxh@tust.edu.cn 
a fatty acid tail linked to a peptide moiety consisting of 7 amino acid residues (6).

For preparation of the inoculum, Bacillus natto TK-1 was grown in a nutrient broth medium at $37^{\circ} \mathrm{C}, 170 \mathrm{rpm}$ for $16 \mathrm{~h}$. The fermentation medium used for biosurfactant production was composed of $5.0 \mathrm{~g} / \mathrm{L}$ sucrose, $20.0 \mathrm{~g} / \mathrm{L}$ peptone, $0.5 \mathrm{~g} / \mathrm{L}$ yeast extract, $0.02 \mathrm{~g} / \mathrm{L} \mathrm{MgSO}_{4} \cdot 7 \mathrm{H}_{2} \mathrm{O}, 1.4 \mathrm{~g} / \mathrm{L} \mathrm{Na}_{2} \mathrm{HPO}_{4} \bullet 12 \mathrm{H}_{2} \mathrm{O}$, and 0.4 $\mathrm{g} / \mathrm{L} \mathrm{KH}_{2} \mathrm{PO}_{4}$, which was inoculated by $1.8 \mathrm{ml}$ of the seed medium into a 500-ml flask with $60 \mathrm{ml}$ fermentation medium. The bacterial cells were then incubated under the same condition as the seed cultures for $24 \mathrm{~h}$.

Ten microorganisms were used as test organisms in this study. Five bacterial strains were obtained from ATCC (American Type and Collection Center), including Micrococcus luteus (ATCC 28001), Salmonella typhimurium (ATCC 14028), Escherichia coli (ATCC 27325), Bacillus cereus (ATCC 7004), Staphylococcus aureaus (ATCC 10780). Five fungal strains, Botrytis cinerea, Fusarium moniliforme, Penicillium candidum, Gibberella zeae and Colletotrichum truncatum were provided by TUST Collection Center (Tianjin University of Science and Technology, Tianjin, China). Bacterial strains were cultivated at $37^{\circ} \mathrm{C}$ and maintained on LB broth. Cultures of fungi were grown on potato dextrose agar (PDA) at $28^{\circ} \mathrm{C}$.

Human chronic myelogenous leukemia cells (K562), human hepatic carcinoma cells (BEL-7402), buffalo rat liver cells (BRL) and human embryonic kidney cells (HEK293) were obtained from Cell Bank of Shanghai Institute of Cell Biology (Shanghai, China) and cultured in RPMI 1640 medium containing 10\% (v/ v) heat-inactivated fetal bovine serum, $100 \mathrm{kU} / \mathrm{L}$ penicillin, 100 $\mathrm{mg} / \mathrm{L}$ streptomycin and $1 \%$ glutamine. All cells were cultured at $37^{\circ} \mathrm{C}$ in a humidified incubator containing $5 \% \mathrm{CO}_{2}$. Cells in logarithmic growth phase were used for further experiments.

The preparation of biosurfactant was described previously by Cao et al. (6). Briefly, the bacterial cells were removed by centrifugation at $10000 \mathrm{rpm}$ at $4^{\circ} \mathrm{C}$ for $10 \mathrm{~min}$. The supernatant was subjected to acid precipitation by adding $6 \mathrm{M} \mathrm{HCl}$ to $\mathrm{pH} 2.0$ and putting the precipitate to form at $4^{\circ} \mathrm{C}$ overnight. The precipitate was collected by centrifugation and resuspended by a little distilled water adjusted to $\mathrm{pH} 7.0$ to make most of precipitate dissolved and finally lyophilized. The brown lyophilized material was then extracted three times with methanol. After evaporation, the crude biosurfactant was isolated by thin-layer chromatography (TLC) on a silica gel plate with a developing solvent consisting of chloroformmethanol-water $(65: 25: 4[\mathrm{vol} / \mathrm{vol} / \mathrm{vol}])$. Then the purified single point was scratched off from the TLC plate to test whether the point contained the biosurfactant by oil spreading (26). The crude biosurfactant was used for further studies.

The surface tensions of various concentrations of biosurfactant were determined by the Ring method using a SIGMA70 system unit tensiometer (KSV Instruments, Trumbull, $\mathrm{CT})$. Measurements were performed at $20^{\circ} \mathrm{C}$. The whole experiment was repeated at least three times. The critical micelle concentration (CMC) was determined as the intersection of the linear part of this curve of surface tension $v s$. the concentration. Furthermore, the surface activity of biosurfactant was also measured by an oil spreading test (26). Briefly, $30 \mathrm{ml}$ distilled water at $\mathrm{pH} 7.0$ was added to a petri dish ( $90 \mathrm{~mm}$ diameter) and then $1.0 \mathrm{ml}$ paraffin oil to the surface of water. When the water was covered by the oil completely, $5 \mu \mathrm{l}$ biosurfactant with various concentrations was put on the center of the oil membrane. The size of the resultant oil-displaced circle area reflects the surface activity of biosurfactant. Each sample was repeated in triplicate and the control plate was evaluated with buffer (PBS).

The anti-adhesive activity of the crude biosurfactant against the bacterial strains was quantified according to a previously reported adhesion assay (23). Briefly, each well of a sterile 96well microtiter plate was filled with $200 \mu \mathrm{l}$ biosurfactant of several concentrations (ranging from 2.5 to $40 \mathrm{~g} / \mathrm{L}$ ) and incubated for $24 \mathrm{~h}$ at $4^{\circ} \mathrm{C}$, and then washed twice with PBS. Control wells contained PBS only. A $200 \mu \mathrm{l}$ aliquot of a washed bacterial suspension was added and incubated in the wells for $4 \mathrm{~h}$ at $4^{\circ} \mathrm{C}$. Unattached organisms were removed by washing the wells three times with PBS. The adherent microorganisms were fixed with $200 \mu \mathrm{l}$ of $99 \%$ methanol per well, and after $10 \mathrm{~min}$ the plates were emptied and left to dry. Then the plates were stained with $1 \%$ crystal violet solution at room temperature for $5 \mathrm{~min}$. Excess stain was rinsed of by placing the plate under running tap water. Subsequently the plates were air dried, the dye bound to the adherent microorganisms was resolubilized with $200 \mu \mathrm{l}$ of $33 \%$ (v/v) glacial acetic acid per well. The absorbance of the dissolved dye, corresponding to the number of adherent microorganisms, was measured in a microplate reader at $595 \mathrm{~nm}$. The percentage reduction in adherence was calculated using the following equation:

\%reduction in adherence $=\left[\left(\mathrm{A}_{\text {control }}\right)-\left(\mathrm{A}_{\text {sample }}\right)\right] / \mathrm{A}_{\text {control }} \times 100$

The disc diffusion method (42) was used to evaluate the antimicrobial activity of biosurfactant. Briefly, the microorganisms were prepared by mixing $1 \mathrm{ml}$ of inoculum (adjusted to $2-5 \times 10^{7} \mathrm{CFU} / \mathrm{ml}$ ) with $15 \mathrm{ml}$ respective medium (LB for bacteria and PDA for fungi) at $45^{\circ} \mathrm{C}$ and allowed to set in a petri dish ( $90 \mathrm{~mm}$ diameter). Wells were then made $(8 \mathrm{~mm}$ diameter) with a sterile cork borer. $30 \mu \mathrm{l}$ of the test solutions and control were added to each disc, respectively. Petri dishes were incubated at $37^{\circ} \mathrm{C}$ during $24 \mathrm{~h}$ for bacteria strains and at $28^{\circ} \mathrm{C}$ during $36 \mathrm{~h}$ for fungi strains. At the end of the incubation period, the presence of clear inhibition zones around the discs was measured. The experiments were carried out in triplicate.

Then, we further observed the morphological changes of $S$. typhimurium in response to biosurfactant treatment by AFM. The AFM analysis was performed as described by Li et al. $(2,22)$. Briefly, S. typhimurium in LB were collected by centrifugation $(10000 \mathrm{rpm}, 10 \mathrm{~min})$ and resuspended in deionized distilled water. Two samples were prepared: one was untreated, 
the other was treated with biosurfactant $(3.2 \mathrm{~g} / \mathrm{L}$ for both organisms). After the samples were incubated at $37^{\circ} \mathrm{C}$ for 50 $\mathrm{min}$, all organisms were collected by centrifugation $(10000 \mathrm{rpm}$, $10 \mathrm{~min}$ ) and resuspended in deionized distilled water again. A $6 \mu \mathrm{l}$ drop of bacteria suspension was applied onto a glass slide. All organisms morphology was observed with AFM (JSPM5200, Nanoscope, Japan) in tapping mode. A single-crystal silicon cantilever was used and the AFM data were collected at a typical line scan rate of $1.0 \mathrm{~Hz}$.

Cell viability was determined by a colorimetric $3-(4,5-$ dimethylthiazol-2-yl)-2, 5-diphenyl tetrazolium bromide (MTT) assay (31). Briefly, exponentially growing cells $\left(1 \times 10^{5} / \mathrm{ml}\right)$ were added to each well of 96-well tissue culture plate with a total volume of $100 \mu \mathrm{l}$ per well. The biosurfactant at various concentrations was added to each well. After cultured with biosurfactant for $48 \mathrm{~h}$, MTT ( $5 \mathrm{mg} / \mathrm{ml}$ in PBS) was added and incubated for $4 \mathrm{~h}$. The formazan precipitate was dissolved in $150 \mathrm{ml}$ DMSO and the absorbance at $570 \mathrm{~nm}$ was measured by an ELISA reader (Multiskan EX, Labsystems). The 50\% inhibitory concentration $\left(\mathrm{IC}_{50}\right)$ of biosurfactant in cells was calculated by MTT assay. In addition, 5-fluorouacil (5-FU) was used as a standard drug.

The chromatin condensation of BEL-7402 cells was analyzed by fluorescence microscopy. Briefly, BEL-7402 cells were treated with biosurfactant $(20 \mathrm{mg} / \mathrm{L})$ for $48 \mathrm{~h}$ with a combination of the fluorescent DNA-binding dyes Hochest 33258 (Sigma). Cells were harvested and washed two times with PBS (pH 7.2), and then were labeled by $10 \mathrm{mg} / \mathrm{L}$ Hochest 33258 for $5 \mathrm{~min}$. The cells were then observed under a fluorescence microscope (Olympus, Japan) using an ultraviolet (UV) filter pack.

After isolation of the biosurfactant by acidic precipitation followed by solvent extraction, the purification was followed by TLC. The surface-active substances migrated at the position of Rf 0.58-0.60 as a single point on the TLC. The relationship between surface tension and concentration of the crude biosurfactant was determined by the Ring method. CMC is defined by the solubility of a surfactant within an aqueous phase and is commonly used to measure the efficiency of a surfactant. The CMC of the crude biosurfactant was estimated to be around $512 \mathrm{mg} / \mathrm{L}$ and the minimum surface tension of biosurfactant was $30.1 \mathrm{mN} / \mathrm{m}$ (Fig. 1a). Although the isolated biosurfactant was not as effective as many of biosurfactants described in the literature, for example, surfactin produced by B. subtilis ATCC 21332 with a CMC of $250 \mathrm{mg} / \mathrm{L}$ and the minimum surface tension $27.9 \mathrm{mN} / \mathrm{m}$ (8), it should be noted that the biosurfactant studied here was not as much purified as the ones described in the literature. In addition, the area of the oildisplaced circle was in good proportion to the concentration of the biosurfactant (Fig. 1b). The higher diameters represent the higher concentration of biosurfactant.

In recent years, the remarkable increase in drug-resistant bacteria makes a search for novel means and drugs of fighting

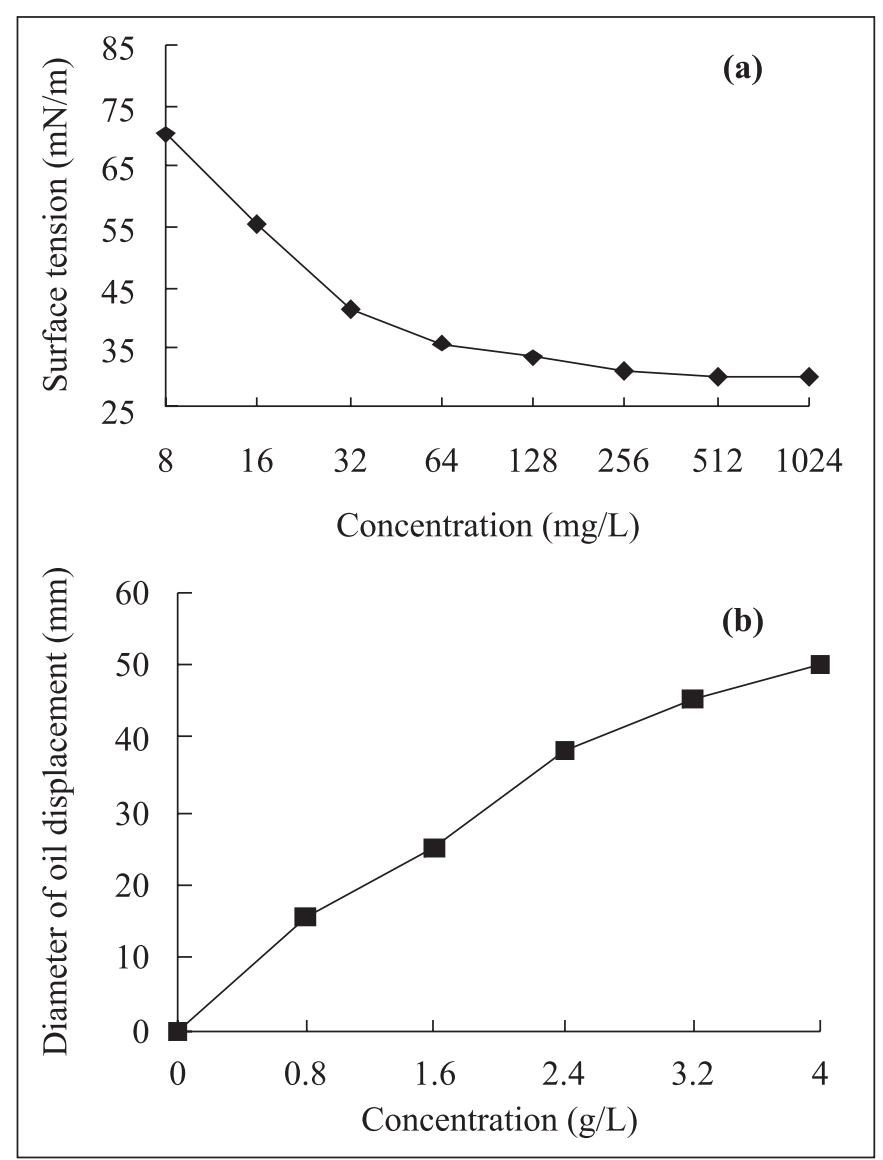

Figure 1. (a) Surface tensions of biosurfactant at various concentrations. Surface tension was measured by the Ring method at $20^{\circ} \mathrm{C}$; (b) Relationship between diameter of oil displacement and various concentrations of biosurfactant. Each sample was repeated in triplicate and the control plate was evaluated with PBS.

bacterial infections imperative. Attempts to reduce or inhibit microbial adherence is a viable means to control infection, since such adherence is one of the initial stages of the infectious process. Biosurfactants have been found to inhibit the adhesion of pathogenic organisms to solid surfaces or to infection sites (34). A biosurfactant of $P$. fluorescens was found to inhibit the adhesion of Listeria monocytogenes LO28 to polytetrafluoroethylene and stainless steel surfaces (30). There are reports of inhibition of biofilm formed by uropathogens and yeast on silicone rubber by biosurfactants produced by Lactobacillus acidophilus (43). Lactobacillus fermentum RC-14 releases surface-active components that can inhibit adhesion of uropathogenic bacteria, including Enterococcus faecalis (11). The mechanism of antiadhesive properties of many drugs appears to be alteration of cell surface hydrophobicity. 
To further test anti-adhesive activity of the biosurfactant, we measured the adherence of a variety of bacteria to 96- well microtiter plates in vitro. As shown in Table 1, the biosurfactant was found to significantly inhibit the adhesion of $S$. typhimurium, E.coli and S. aureaus. The highest anti-adhesive activity was exhibited against $S$. typhimurium with inhibition percentage till $51.9 \%$. Results obtained from all treated bacteria indicated that the anti-adhesive effect depended on the dose applied and the bacteria tested. The anti-adhesive activity against $M$. luteus will occur when the concentration of biosurfactant is higher than $6.4 \mathrm{~g} / \mathrm{L}$.

Zones of inhibition diameter produced by different concentrations of biosurfactant were measured using disc diffusion method. As shown in Table 2 and Fig. 2, biosurfactant exhibited interesting antibacterial and antifungal activities. The antimicrobial activity increased with increasing concentration

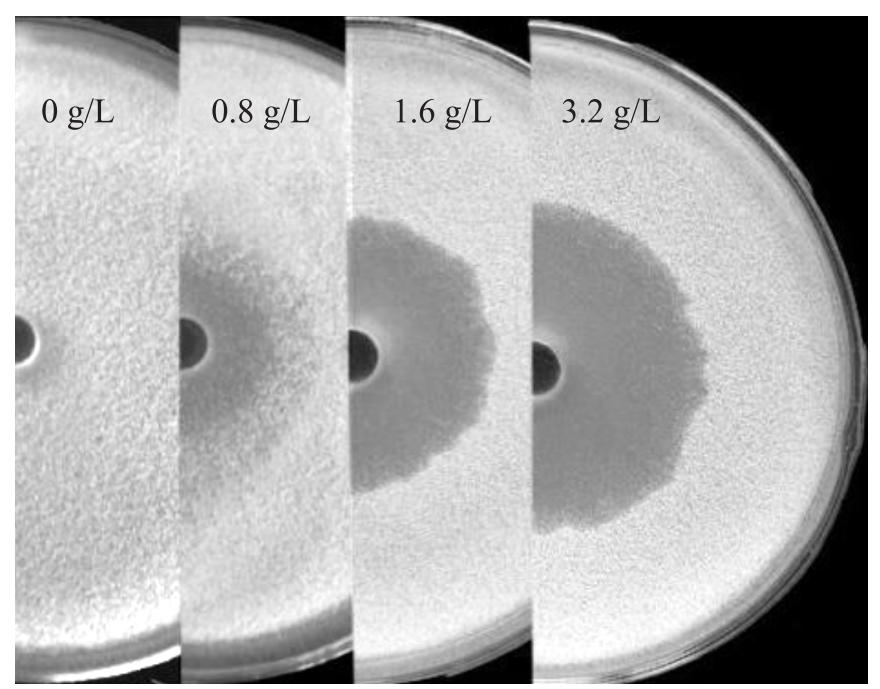

Figure 2. Antimicrobial activity of biosurfactant at various concentrations (0-3.2 g/L) against B. cinerea.
Table 2. Antibacterial and antifungal activities of the crude biosurfactant at different concentrations $(0.8-3.2 \mathrm{~g} / \mathrm{L})$ using disc diffusion method.

\begin{tabular}{lccc}
\hline \multirow{2}{*}{ Microorganisms } & \multicolumn{3}{c}{$\begin{array}{c}\text { Zone of inhibition } \\
\text { diameter(mm) }\end{array}$} \\
\cline { 2 - 4 } & $0.8 \mathrm{~g} / \mathrm{L}$ & $1.6 \mathrm{~g} / \mathrm{L}$ & $3.2 \mathrm{~g} / \mathrm{L}$ \\
\hline Bacteria & & & \\
Micrococcus luteus & 8.1 & 13.4 & 18.0 \\
Salmonella typhimurium & 7.4 & 10.3 & 12.0 \\
Staphylococcus aureaus & 7.7 & 9.0 & 11.4 \\
Bacillus cereus & - & - & - \\
Escherichia coli & - & - & - \\
Fungi & & & \\
Botrytis cinerea & 38.2 & 41.3 & 48.8 \\
Fusarium moniliforme & 16.5 & 20.1 & 28.4 \\
Colletotrichum truncatum & 6.7 & 7.3 & 11.4 \\
Penicillium candidum & 6.1 & 8.4 & 10.8 \\
Gibberella zeae & - & - & - \\
\hline
\end{tabular}

'- ' = no inhibition.

of biosurfactant. It has a strong activity against $B$. cinerea, $F$. moniliforme, $M$. luteus and $S$. typhimurium. Recently, several lipopeptide biosurfactants produced by $B$. subtilis $(21,36,44)$ and $B$. licheniformis $(9,13,46)$ have been shown to have antimicrobial activity. Vater et al. (41) had described the antifungal properties of surfactin. Hiradate et al. (12), Yu et al. (47) and Cho et al. (7), reported about another lipopeptide, iturin, produced by Bacillus strains to suppress phytopathogenic fungi. In our study, the lipopeptide biosurfactant from Bacillus natto TK-1 exhibited both antibacterial and antifungal activities.

Previous studies showed that various interesting biological properties of lipopeptide biosurfactants were presumed to be the result of interactions with the membranes of target cells

Table 1. The anti-adhesive activity of the crude biosurfactant at different concentrations (0.8-12.8 g/L) against a variety of bacteria to $96-$ well microtiter plates in vitro.

\begin{tabular}{lccccc}
\hline \multirow{2}{*}{ Bacteria } & \multicolumn{5}{c}{ Mean \% reduction in adherence } \\
\cline { 2 - 6 } & $0.8 \mathrm{~g} / \mathrm{L}$ & $1.6 \mathrm{~g} / \mathrm{L}$ & $3.2 \mathrm{~g} / \mathrm{L}$ & $6.4 \mathrm{~g} / \mathrm{L}$ & $12.8 \mathrm{~g} / \mathrm{L}$ \\
\hline Salmonella typhimurium & 5.3 & 9.7 & 18.5 & 28.4 & 51.9 \\
Escherichia coli & 4.1 & 9.0 & 19.8 & 30.6 & 44.3 \\
Staphylococcus aureaus & 4.9 & 7.5 & 16.5 & 20.7 & 30.2 \\
Micorococcus luteus & - & - & - & 5.9 & 11.2 \\
Bacillus cereus & - & - & - & - & - \\
\hline
\end{tabular}

'-_' = no reduction in adherence. 
(37). By Scanning electron and optical microscopies, Thimon et al. (39) discovered iturin produced by B. subtilis, which affects the morphology and membrane structure of yeast cells. Studies by Kim et al. (20) also proved that fengycin from $B$. thuringiensis CMB26 was capable of affecting the cell surface of the phytopathogenic fungus $C$. gloeosporioides, an of the bacteria E. coli $\mathrm{O} 157$ and $P$. rapaecrucivora. In our study, the bactericidal effects upon $S$. typhimurium were examined using AFM. It can be observed from the images that before treatment of biosurfactant the $S$. typhimurium showed normal smooth surfaces. Meanwhile, clustering of cells was observed. In contrast, cells treated with biosurfactant for 50 min exhibited dramatic changes in the structure of the cell walls. The outer membrane of the bacteria was extremely rough and some membrane residues were found around the cells. Cells were scattered and few clustering were seen (data not shown).

In recent years, there are few reports about lipopeptide biosurfactants with effect on tumor cells. As part of our program to evaluate the cytotoxic potential of the biosurfactant, K562 and BEL-7402 cells were treated with a series of biosurfactant concentrations for $48 \mathrm{~h}$, and then cell viability was evaluated by MTT assay. The results in Fig. 3a showed that biosurfactant was able to suppress the viability of K562 and BEL-7402 cells in a dose- dependent manner. The $\mathrm{IC}_{50}$ for $\mathrm{K} 562$ and BEL-7402 cells at $48 \mathrm{~h}$ were $19.1 \mathrm{mg} / \mathrm{L}$ and $30.2 \mathrm{mg} / \mathrm{L}$, respectively. In addition, the effects of biosurfactant on the survival rate of normal cell lines were also examined, including BRL and HEK293. The $\mathrm{IC}_{50}$ for BRL and HEK293 cells at $48 \mathrm{~h}$ were $105.4 \mathrm{mg} / \mathrm{L}$ and $93.8 \mathrm{mg} / \mathrm{L}$, respectively (Fig. 3b). Compared with K562 and BEL7402 cells, biosurfactant at the same concentration had lower toxicity to the normal cell lines in vitro.

Direct observation of the cells under the fluorescent microscope tends to suggest that biosurfactant induces apoptosis of BEL-7402 cells. The nuclear morphology was analyzed by Hochest 33258 staining. Cytoplasm and chromatin condensation, were detected in BEL-7402 cells at $48 \mathrm{~h}$ of treatment with $20 \mathrm{mg} / \mathrm{L}$ biosurfactant (data not shown). Apoptosis is a tightly regulated form of cell death, also called the programmed cell death (35). It has a central role in the pathogenesis of human disease when the genes controlling the apoptotic process are suppressed, overexpressed or altered by mutation (38). Disordered apoptosis is implicated in a variety of human diseases. Research into apoptosis is proceeding at a fast pace and this has led to the possibility of new therapeutic approaches to some tumor diseases (16). Our study demonstrated that the biosurfactant induced morphological changes. BEL-7402 cells treated with biosurfactant were characterized by chromatin condensation and cell shrinkage in the early stage, and then the nucleus and cytoplasm fragment, forming membrane-bound apoptotic bodies which can be engulfed by phagocytes.

In the present study, the biosurfactant produced by Bacillus natto TK-1 has a strong surface activity. From the results of
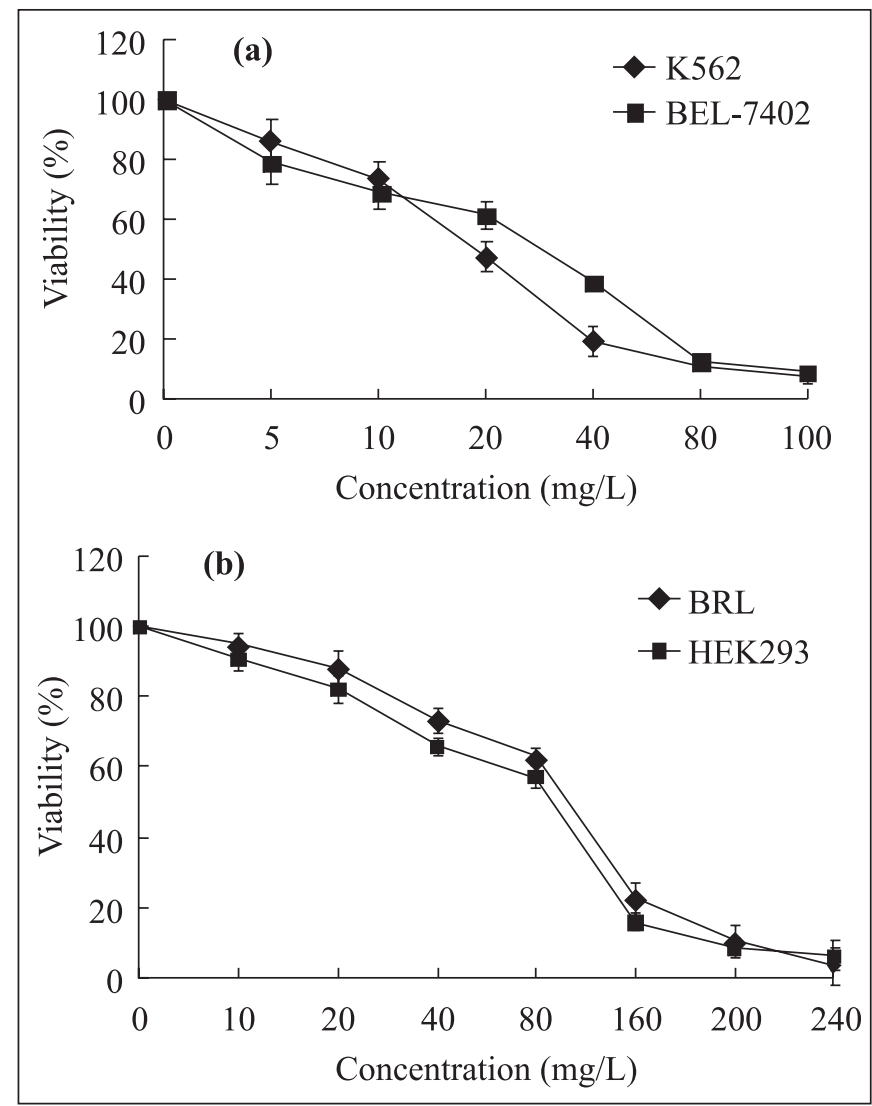

Figure 3. Effects of biosurfactant on the viability of tumor and normal cells. K562 and BEL-7402 cells (a), and BRL and HEK293 (b) were treated with biosurfactant at the indicated concentrations for $48 \mathrm{~h}$. The viability was determined by MTT assay. Each value represents mean \pm S.D. of three independent experiments.

anti- adhesive, antimicrobial and antitumor activities assay, biosurfactant exhibits attractive therapeutical and biotechnological properties, which represents a promising candidate as a new drug. The information of the morphological changes of bacteria provided by AFM indicated that the disruption of the outer membrane of $S$. typhimurium cells was the possible mechanism of the action of the lipopeptide biosurfactant. In addition, by fluorescence examination, biosurfactant induced chromatin condensation of BEL-7402 cells and showed common features of apoptosis.

\section{ACKNOWLEDGEMENTS}

The authors gratefully acknowledge the financial support by the National Natural Science Foundation of China under grant number 20676103. We would also like to thank Xiao-Qing Zhang for the use of the atomic force microscope. 


\section{RESUMO}

\section{Avaliação de um lipopeptídio biosurfactante de Bacillus natto TK-1 com fonte potencial de atividade antiadesiva, antimicrobiana e antitumoral}

Um lipopeptídio biosurfactante produzido por Bacillus natto TK-1 apresenta intensa atividade de superfície. Verificou-se que o biosurfactante apresentou atividade antiadesiva contra várias cepas bacterianas, e também atividade antimicrobiana de amplo espectro. O biosurfactante causou uma redução significativa na viabilidade de células tumorais, de forma dose-dependente.

Palavras-chave: biosurfactante, atividade antiadesiva, atividade antimicrobiana, atividade antitumoral

\section{REFERENCES}

1. Arima, K.; Kakinuma, A.; Tamura, G. (1968). Surfactin, a crystalline peptidelipid surfactant produced by Bacillus subtilis: isolation, charactization and its inhibition of fibrin clot formation. Biochem. Biophys. Res. Commun., 31, 488-494.

2. Arnaldo, S.J.; Omar, T. (2003). Effects of the antimicrobial peptide PGLa on live Escherichia coli. Biochim. Biophys. Acta., 1643, 95-103.

3. Banat, I.M. (1995). Characterization of biosurfactants and their use in pollution removal-state of the art (Review). Acta. Biotechnol., 15, 251-267.

4. Bernheimer, A.W.; Avigad, L.S. (1970). Nature and properties of a cytolytic agent produced by Bacillus subtilis. J. Gen. Microbiol., 61, 361-369.

5. Besson, F.; Michel, G. (1992). Biosynthesis of iturin and surfactin by Bacillus subtilis: evidence for amino acid activating enzymes. Biotechnol. Len., 14, 1013-1018.

6. Cao, X.H.; Cai, P.; Li, F.; Wang, C.L.; Lu, M.F. (2007). Medium optimization for lipopeptide produced by Bacillus natto TK-1 using response surface methodology. China Biotechnol., 27, 59-65.

7. Cho, S.J.; Lee, S.K.; Cha, B.J.; Kim, Y.H.; Shin, K.S. (2003). Detection and characterization of the Gloeosporium gloeosporioides growth inhibitory compound iturin A from Bacillus subtilis strain KS03. FEMS Microbiol. Lett., 223, 47-51.

8. Cooper, D.G.; Macdonald, C.R.; Duff, S.J.B.; Kosaric, N. (1981). Enhanced production of surfactin from Bacillus subtilis by continuous product removal and metal cation additions. Appl. Environ. Microbiol., 42, 408-412.

9. Fiechter, A. (1992). Biosurfactants: moving towards industrial application. Trends Biotechnol., 10, 208-217.

10. Fujita, M.; Nomura, K.; Hong, K.; Ito, Y.; Asada, A.; Nishimuro, S. (1993). Purification and characterization of a strong fibrinolytic enzyme (nattokinase) in the vegetable cheese natto, a popular soybean fermented food in Japan. Biochem. Biophys. Res. Commun., 197, 1340-1347.

11. Heinemann, C. (2000). Purification and characterization of a surfacebinding protein from Lactobacillus fermentum RC-14 that inhibits adhesion of Enterococcus faecalis 1131. FEMS Microbiol. Lett., 190, 177-180.

12. Hiradate, S.; Yoshida, S.; Sugie, H.; Yada, H.; Fujii, Y. (2002). Mulberry anthracnose antagonists (iturins) produced by Bacillus amyloliquefaciens RC-2. Phytochemi., 61, 693-698.

13. Jenny, K.; Kappeli, O.; Fiechter, A. (1991). Biosurfactants from Bacillus licheniformis, structural analysis and characterization. Appl. Microbiol. Biotechnol., 36, 5-13.
14. Ju, H.K.; Jun, P.Y.; Lei, Z.; Yi, P.Q. (2004). Identification of two novel fibrinolytic enzymes from Bacillus subtilis QK02. Comparative. Biochem. Physio. Part C., 137, 65-74.

15. Kakinuma, A.; Ouchida, A.; Shima, T.; Sugino, H.; Isono, M.; Tamura, G.; Arima, K. (1969). Confirmation of the structure of surfactin by mass spectrometry. Agric. Biol. Chem., 33, 1669-1671.

16. Kam, P.C.A.; Ferch, N.I. (2000). Apoptosis: mechanisms and clinical implications. Anaesthesia., 55, 1081-1093.

17. Kameda, Y.; Matsui, K.; Hisato, K.; Yamada, T.; Sagai, H. (1972). Antitumor activity of Bacillus natto. III. Isolation and characterization of a cytolytic substance on Ehrlich ascites carcinoma cells in the culture medium of Bacillus natto KMD 1126. Chem. Pharm. Bull., 20, 1551-1553.

18. Khire, J.M.; Khan, M.I. (1994). Microbes and the subsurface environment. Enz. Microbiol. Technol., 16, 258-259.

19. Kim, H.S.; Yoon, B.D.; Choung, D.H.; Oh, H.M.; Katsuragi, T.; Tani, Y. (1999). Characterization of a biosurfactant, mannosylerythritol lipid, produced from Candida sp. SY16. Appl. Microbiol. Biotechnol., 52, 713-721.

20. Kim, P.I.; Bai, H.; Bai, D.; Chae, H.S.; Chung, Y.; Kim, R. (2004). Purification and characterization of a lipopeptide produced by Bacillus thuringiensis CMB26. J. Appl. Microbiol., 97, 942-949.

21. Leenhouts, J.M. (1995). Anionic phospholipids can mediate membrane insertion of the anionic part of a bound peptide. FEBS. Lett., 370, 361-369.

22. Li, A.; Lee, P.Y.; Ho, B.; Ding, J.L.; Lim, C.T. (2007). Atomic force microscopy study of the antimicrobial action of Sushi peptides on Gram negative bacteria. Biochim. Biophys. Acta., 1768, 411-418.

23. Lígia, R.; Rodrigues, J.A.; Teixeira, H.C.M.; Rosário, O. (2006). Physicochemical and functional characterization of a biosurfactant produced by Lactococcus lactis 53. Colloids. Surfaces B: Biointerfaces., 49, 79-86.

24. Magetdana, R.; Thimon, L.; Peypoux, F.; Ptak, M. (1992). Surfactin/ iturin A interactions may explain the synergistic effect of surfactin on the biological properties of iturin A. Biochem., 74, 1047-1051.

25. Maier, R.M.; Soberon, C.G. (2000). Pseudomonas aeruginosa rhamnolipids: biosynthesis and potential applications. Appl. Microbiol. Biotechnol., 54, 625-633.

26. Masaaki, M.; Hiromi, D.; Toshifumi, T.; Satoru, M.; Yasutsugu, S.; Tadayuki, I. (1993). A New lipopeptide biosurfactant produced by Arthrobacter sp. strain MIS38. J. Bacteriology., 175, 6459-6466.

27. Mecke, A.; Lee, D.K. (2005). Membrane thinning due to antimicrobial peptide binding: an atomic force microscopy study of MSI-78 in lipid bilayers. J. Biophys., 89, 4043-4050.

28. Mecke, A.; Lee, D.K.; Ramamoorthy, A.; Orr, B.G.; Holl, M.M. (2005). Synthetic and natural polycationic polymer nanoparticles interact selectively with fluid-phase domains of DMPC lipid bilayers. Langmuir., 21, 8588-8590.

29. Mecke, A.; Uppuluri, S.; Sassanella, T.M.; Lee, D.K. (2004). Direct observation of lipid bilayer disruption by poly (amidoamine) dendrimers, Chem. Phys. Lipids., 132, 3-14.

30. Meylheuc, T. (2001). Adsorption of biosurfactant on solid surfaces and consequences regarding the bioadhesion of Listeria monocytogenes LO28. J. Appl. Microbiol., 91, 822-832.

31. Nakagawa, H.; Yamamoto, D.; Kiyozuka, Y.; Tsuta, K.; Uemura, Y.; Hioki, K.; Tsutsui, Y.; Tsubura, A. (2000). Effects of genistein and synergistic action in combination with eicosapentaenoic acid on the growth of breast cancer cell lines. J. Cancer Res. Clin. Oncol., 126, 488-494.

32. Parkinson, M. (1985). Biosurfactants. Biotechnol. Adv., 3, 65-83.

33. Peypoux, F.; Bonmatin, J.M.; Wallach, J. (1999). Recent trends in the biochemistry of surfactin. Appl. Microbiol. Biotechnol., 51, 553-563.

34. Pooja, S.; Swaranjit, S.C. (2004). Potential applications of microbial surfactants in biomedical sciences. Trends.Biotechnol., 22, 208-214. 
35. Reed, J.C. (2001). Apoptosis-regulating proteins as targets for drug discovery. Trend. Mol. Med., 7, 314-319.

36. Sandrin, C.; Peypoux, F.; Michel, G. (1990). Coproduction of surfactin and iturin A lipopeptides with surfactant and antifungal properties by Bacillus subtilis. Biotechnol. Appl. Biochem., 12, 370-375.

37. Sheppard, J.D.; Jumarie, C.; Cooper, D.G.; Laprade, R. (1991). Ionic channels induced by surfactin in planar lipid bilayer membranes. Biochem. Biophys. Acta., 1064, 13-23.

38. Thatte, U.; Dahanukar, S. (1997). Apoptosis-clinical relevance and pharmacological manipulation. Drugs., 54, 511-532.

39. Thimon, L.; Peypoux, F.; Wallach, J.; Michel, G. (1995). Effect of the lipopeptide antibiotic iturin A, on morphology and membrane ultrastructure of yeast cells. FEMS. Microbiol. Lett., 128, 101-106.

40. Tomohiro, H.; Rieko, H.; Shizue, S.; Akio, A.; Kan, K.; Shuichi, K. (2003). Cytokine responses of human intestinal epithelial-like Caco2 cells to the nonpathogenic bacterium Bacillus subtilis (natto). Inter. J. of Food. Microbiol., 82, 255-264.

41. Vater, P.J. (1986). Lipopeptides, an attractive class of microbial surfactants. Prog. Colloid. Polym. Sci., 72, 12-18.
42. Vázquez, M.M.; González, E.A.R.; Luna, L.C.; Gutiérrez, M.N.M.; García-Argáez, A.N. (1999). Antimicrobial activity of Byrsonima crassifolia (L.) H.B.K. J. Ethnopharmacology., 66, 79-82.

43. Velraeds, M.M. (1998). Interference in initial adhesion of uropathogenic bacteria and yeasts to silicone rubber by a Lactobacillus acidophilus biosurfactant. J. Med. Microbiol., 47, 1081-1085.

44. Vollenbroich, D.; Pauli, G.; Ozel, M.; Vater, J. (1997). Antimycoplasma properties and application on cell cultures of surfactin, a lipopeptide antibiotic from Bacillus subtilis. Appl. Environ. Microbiol., 63, 44-49.

45. Wei, Y.H.; Wang, L.F.; Chang, J.S.; Kung, S.S. (2003). Identification of induced Acidification in Iron-Enriched Cultures of Bacillus subtilis during Biosurfactant Fermentation. J. Biosci. Bioeng., 96, 174-178.

46. Yakimov, M.M.; Timmis, K.N.; Wray, V.; Fredrickson, H.L. (1995). Characterization of a new lipopeptide surfactant produced by thermotolerant and halotolerant subsurface Bacillus licheniformis BAS 50. Appl. Environ Microbiol., 61, 1706-1713.

47. Yu, G.Y.; Sinclair, J.B.; Hartman, G.L.; Bertagnolli, B.L. (2002) Production of iturin A by Bacillus amyloliquefaciens suppressing Rhizoctonia solani. Soil Biol. Biochemie., 34, 955-963. 